\title{
Differential Scanning Calorimetry on Fish Meat Paste
}

\author{
Naomichi Iso, ${ }^{* 1}$ Haruo Mizuno, ${ }^{* 1}$ Hiroo Ogawa, ${ }^{* 2}$ \\ Yoshinori Mochizuki, ${ }^{* 3}$ and Norio Masuda*1 \\ (Received July 18, 1990)
}

\begin{abstract}
The thermal measurements using a differential scanning calorimeter was done with 10 kinds of fish meat, cuttlefish meat paste, and chicken meat paste. The total enthalpy change, $\Delta H$, accompanied with the thermal gelation of meat pastes were estimated. Consequently, it was found that the easy-setting meat and the easy-disintegrating meat required a small quantity of heat in order to change the structure. The setting index $(S)$ and the disintegration index $(D)$ reported by Shimizu et al. depends on the $\lrcorner H$-values as follows;

$$
\begin{aligned}
& \Delta H=-0.0074 S+1.047 \\
& \Delta H=-0.0038 D+0.783 .
\end{aligned}
$$

Namely, the easy-setting property or the easy-disintegrating property corresponds to the fact that these meat pastes easily changed by a small quantity of heat. On the other hand, the correlation could not be found between $\Delta H$ and the gel-strength reported by Shimizu et al.
\end{abstract}

It is well-known that fish meat paste is converted to a gel by heating. Also, a structure-setting reaction of fish meat paste proceeds at a temperature below $50^{\circ} \mathrm{C}$, and a structure-disintegration reaction of fish meat gel occures at temperature between $50^{\circ} \mathrm{C}$ and $70^{\circ} \mathrm{C}$. The former reaction is so-called 'suwari' and the latter one 'modori'. The structure-setting and disintegration properties are largely varied with species of raw materials.

Shimizu et al. ${ }^{\text {1) }}$ have studied on the both reactions using pastes made from 53 kinds of meat and divided them into 4 groups; a difficult-setting and difficult-disintegrating group, a difficultsetting and easy-disintegrating group, an easysetting and easy-disintegrating group, and an easy-setting and difficult-disintegrating group.

Moreover, Shimizu et al. ${ }^{12}$ have defined the setting index, which is a measure of structuresetting property, and the disintegration index, which is a measure of structure-disintegrating property as follows;

$$
\text { setting index }=\frac{S \cdot e_{30} \mathrm{C} \text { or } 40^{\circ} \mathrm{C}, 2 \mathrm{~h}}{S \cdot e_{80} \mathrm{C} \text { or } 50^{\circ} \mathrm{C}, 2 \mathrm{~h}} \times 100
$$

where $S \cdot e$ is a gel-strength $\left(\mathrm{g} / \mathrm{cm}^{2}\right)$. And the suffix means the heating temperature and the

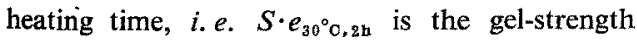

of gel that is heated at $30^{\circ} \mathrm{C}$ for $2 \mathrm{~h}$.

$$
\text { disintegration index }=\left(1-\frac{S \cdot e_{80}{ }^{\circ} \mathrm{c}, 2 \mathrm{~h}}{S \cdot e_{80}{ }^{\circ} \mathrm{c}, 20 \mathrm{mln}}\right) \times 100
$$

On the other hand, several works using thermal analyses have been published on fish meat gels. ${ }^{2-5}$ ) For examples, Takagi") has studied on the water in fish meat gel by differential thermal analyses (DTA) and thermogravimetric analysis (TGA), and Akahane et $a l^{3)}$ have studied on fish meat gels in relation to the jelly strength by differential scanning calorimetry (DSC).

In this work, the DSC study was performed on 12 kinds of meat paste including 10 kinds of fish, cuttlefish, and chicken. Then the correlation between the results obtained and the setting property or disintegrating property was examined.

\section{Materials and Methods}

\section{Materials}

The samples used in this work are summarized in Table 1. All samples were obtained at markets. Namely, the fish samples except carp and bluefin tune were obtained from the fish market at the day performed the DSC experiment. The carp meat was obtained just after killing, and the

*1 Department of Food Science and Technology, Tokyo University of Fisheries, Konan, Minato, Tokyo 108, Japan（磯 直道，水野治夫，增田典生：東京水産大学)，

*2 Yamamoto Nori Research Laboratory, Oomori-Highashi, Oota, Tokyo 143, Japan (小川咸男：山本海 荅研究所).

*3 Laboratory of Food Science, Toyoko Gakuen Women's College, Todoroki, Setagaya, Tokyo 158, Japan (望月義筑：東横学園女子篮期大学). 
Table 1. Samples used in this work*

\begin{tabular}{|c|c|c|c|c|}
\hline Species & (Japanese) & $S$ & $\mathrm{D}$ & S.e \\
\hline Nibe croaker & Nibe & $(30)$ & 98 & 1,560 \\
\hline Flying fish & Tobiuo & $(50)$ & 29 & 1,470 \\
\hline Horse mackerel & Maaji & (9) & 14 & 1,023 \\
\hline Chicken & Niwatori & $4(0)$ & 7 & 894 \\
\hline Bluefin tuna & Kuromaguro & $83 \quad(2)$ & 93 & 879 \\
\hline Spanish mackerel & Sawara & 92 (1) & 95 & 762 \\
\hline Saury pike & Sanma & $72(0)$ & 59 & 624 \\
\hline Carp & Koi & $49 \quad(4)$ & 16 & 600 \\
\hline Common mackerel & Masaba & $65 \quad(4)$ & 97 & 543 \\
\hline Cuttlefish & Kouika & $60 \quad(0)$ & 26 & 543 \\
\hline Sardine & Maiwashi & 100 & 100 & 447 \\
\hline Bonito & Katsuo & 70 & 78 & 321 \\
\hline
\end{tabular}

frozen meat was used for bluefin tuna. The chiken meat was taken from a broiler. All meats were ground down using a porcelain mortar and without water and salt. In Table $1, S, D, S \cdot e$ are the setting index, the disintegration index, and the gel-strength, respectively, reported by Shimizu et $a l .{ }^{1}$ The $S$-values are obtained by substituting $S \cdot e_{40}{ }^{\circ} \mathrm{C}, 2 \mathrm{~h}$ and those in parenthesis are obtained by substituting $S \cdot e_{30^{\circ} \mathrm{o}, 2 \mathrm{H}}$. The $S \cdot e$ values are the gel-strength which are heated at $60^{\circ} \mathrm{C}$ for $20 \mathrm{~min}$.

\section{DSC Measurement}

Thermal measurements were performed with a SSC $560 \mathrm{U}$ Differential Scanning Calorimeter (Seiko Instruments Inc.) at heating rate of $1 \mathrm{~K}$ / min in the temperature range from $30^{\circ} \mathrm{C}$ to $100^{\circ} \mathrm{C}$. Sealed alminium pan, of which volume was $70 \mu l$, was used in all runs. Before using, the pan was treated with boiling water to avoid oxidation of the alminium during measurement. About $20 \mathrm{mg}$ of sample were used for DSC measurement.

\section{Results and Discussion}

Figures 1, 2, and 3 show the DSC thermograms of the meat pastes. That is, the thermograms of meat paste of carp, nibe croaker, horse mackerel, and sardinge are shown in Fig. 1; those of flying fish, saury pike, bonito, and chicken in Fig. 2; those of bluefin tuna, cuttlefish, Spanish mackerel, and common mackerel in Fig. 3. The numerical values in parenthesis in these Figures are the protein contents in meat pastes used.

The DSC thermogram obtained with a measurement of carp meat paste is a simple curve

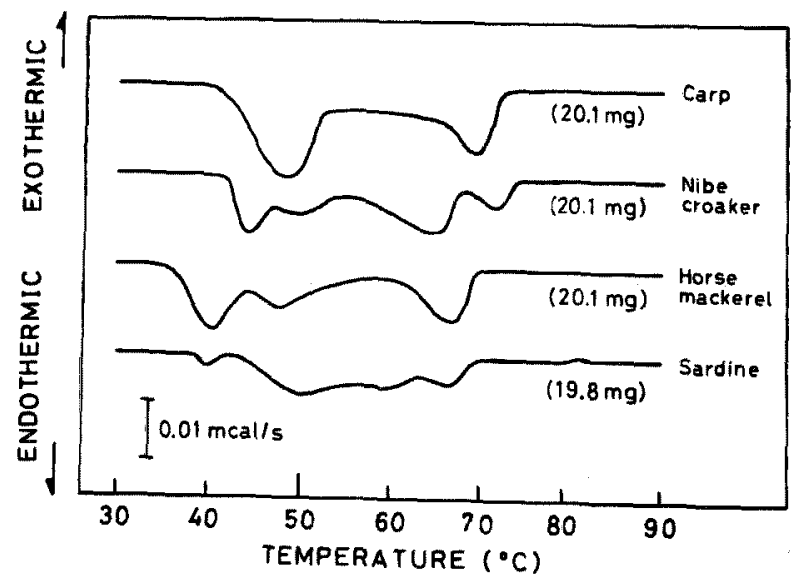

Fig. 1. The DSC thermograms of meat pastes of carp, nibe croaker, horse mackerel, and sardine. The numerical values in parenthesis are the weight of paste used. 


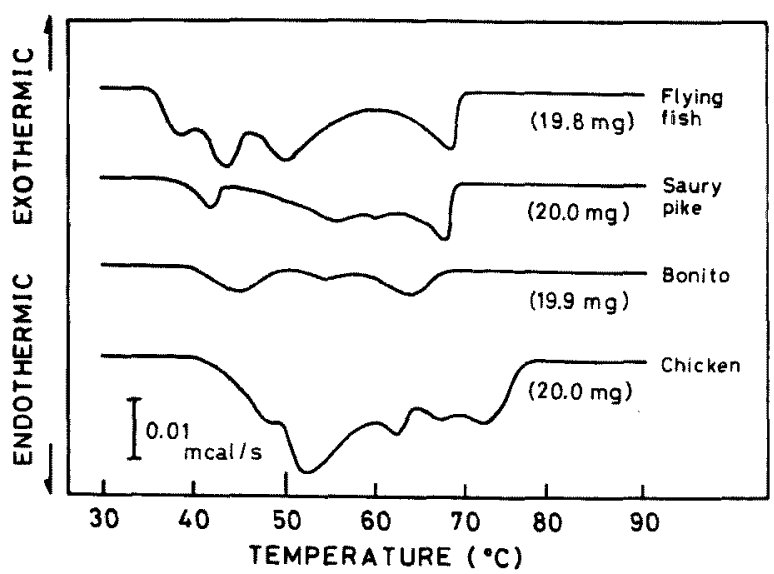

Fig. 2. The DSC thermograms of meat pastes of flying fish, saury pike, bonito, and chicken. The numberical values in parenthesis are the weight of paste used.

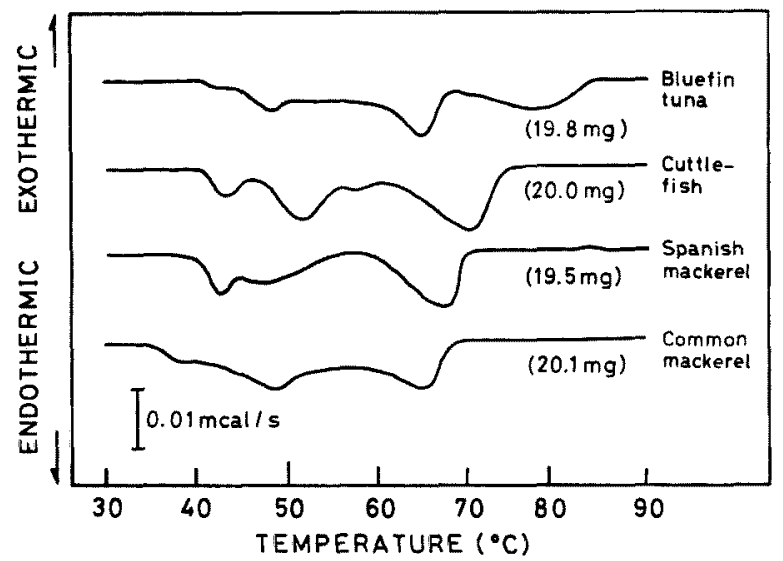

Fig. 3. The DSC thermograms of meat pastes of bluefin tuna, cuttlefish, Spanish mackerel, and common mackerel. The numerical values in parenthesis are the weight of paste used.

which has two endothermic peaks. In our previous work, ${ }^{43}$ it was concluded that the endothermic reaction around $70^{\circ} \mathrm{C}$ was due to the denaturation of actin and the reaction around $50^{\circ} \mathrm{C}$ was due to that of myosin in meat. The thermograms obtained from other samples are not simple as shown in Figs. 1, 2, and 3. Although the endothermic peak around $40^{\circ} \mathrm{C}$ may be due to the denaturation of collagen, the other peaks except those near $70^{\circ} \mathrm{C}$ and $50^{\circ} \mathrm{C}$ have not been ascertained now. Moreover, the shape of the thermogram depends on not only quality and quantity of protein, but also on those of fat and other components in meat. The idea that the shape of thermogran of meat depends on the freshness of sample cannot be neglected. However, the possibility was not taken account in this work, since the all samples used had the quantity to be able to eat raw except chiken.

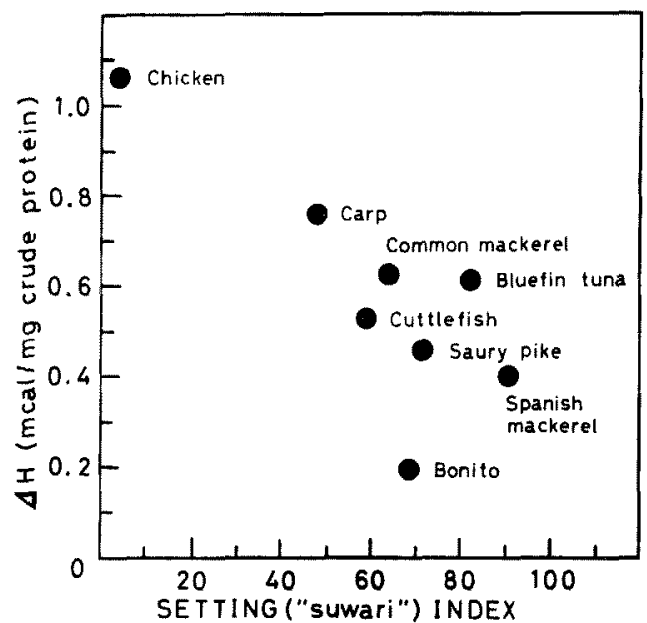

Fig. 4. The correlation between total enthalpy change and setting index. 


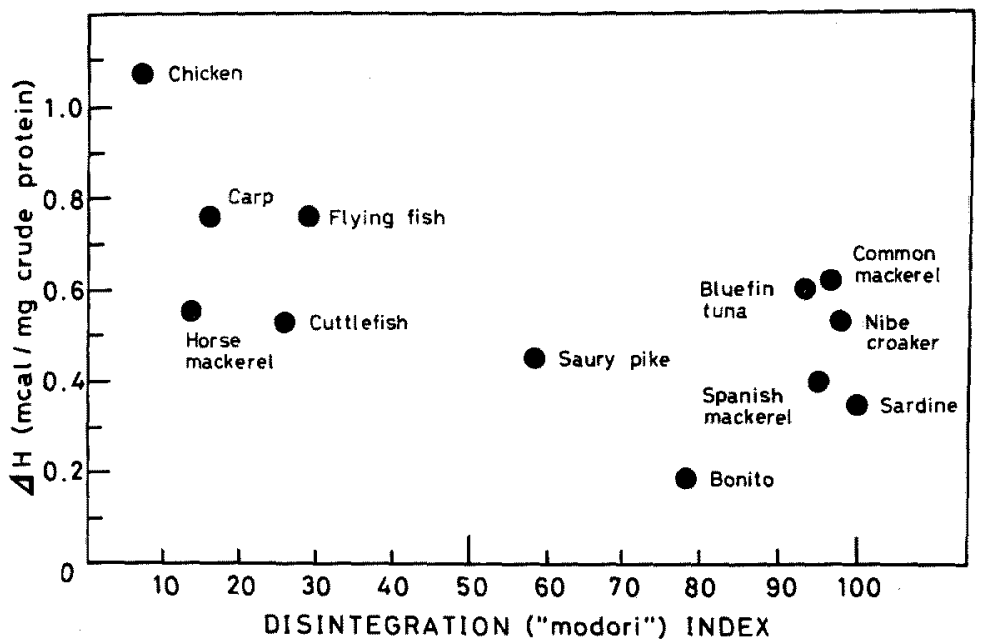

Fig. 5. The correlation between total enthalpy change and disintegration index.

The total enthalpy change, $\Delta H$, is estimated from the area bounded by the thermogram and the base line.

Figure 4 shows the relationship between the setting index $(S)$ reported by Shimizu et al, ${ }^{1)}$ and $\Delta H$. As shown in Fig. $4, \Delta H$ depends on the setting index, that is, the meat paste of easysetting species requires a samll enthalpy to convert to gel. It means that a thermo-reaction occurs by a small quantity of heat in a meat paste of the easy-setting species. An empirical correlation,

$$
\Delta H=-0.0074 S+1.047
$$

was obtained, where $\Delta H$ was the total enthalpy change in $\mathrm{mcal} /(\mathrm{mg}$ of protein). The correlation coefficient was 0.81 .

The dependence of $\Delta H$ on the disintegration index $(D)^{1)}$ is shown in Fig. 5. A meat gel of easy-disintegrating species is easily disintegrated by a small quantity of heat, too. The result of

$$
\Delta H=-0.0038 D+0.783
$$

was obtained empirically, although the data somewhat scattered. The correlation coefficient was 0.69 .

The setting and the disintegrating reactions were endothermic reaction, and the small $\Delta H$ obtained in this experiment means that the structure or conformational changes of meat by heating is completed with small quantity of heat.
On the other hand, the gel-strength ${ }^{13}$ did not depend on $A H$. In this case, the correlation coefficient was 0.31 . The gel strength was estimated from a mechanical test, which did not correspond to thermal reaction. Moreover, on the basis of the consideration that the tendencies of setting and disintegration properties did not correspond to the gel-strength ${ }^{17}$, the results are considered to be reasonable.

The value of $\Delta H$ must be discussed with the quantity and quality of proteins, fats, and other components in meat in future.

\section{References}

1) Y. Shimizu, R. Machida, and S. Takenami: Nippon Suisan Gakkaishi, 47, 95-104 (1981).

2) I. Takagi: in "Shokuhin no Mizu" (ed. by Japan. Soc. Sci. Fish.), Koseisha-Koseikaku, Tokyo, 1973, pp. 95-100.

3) T. Akahane, S. Chihara, Y. Yoshida, T. Tsuchiya, S. Oguchi, H. Oogami, and J. J. Matsumoto: Nippon Suisan Gakkaishi, 47, 105-111 (1981).

4) T. Saito, N. Iso, H. Mizuno, and Y. Mochizuki: Repts. Progr. Polym. Phys. Japan, 27, 745-746 (1984).

5) Y. Mochizuki, T. Saito, N. Iso, H. Mizuno, A. Aochi, and M. Noda: Nippon Suisan Gakkaishi, 53, 1471-1474 (1987). 